\title{
Interleukin 1 Receptor-Like 1 Measurement
}

National Cancer Institute

\section{Source}

National Cancer Institute. Interleukin 1 Receptor-Like 1 Measurement. NCI Thesaurus. Code C142281.

The determination of the amount of interleukin 1 receptor-like 1 present in a sample. 